\title{
SECANG (CAESALPINIA SAPPAN ) : TELAAH AKTIFITAS BIOLOGIS DAN POTENSI PEMANFAATANNYA
}

\author{
Oleh : \\ Irawan W. Kusuma *)
}

\begin{abstract}
Plant resources serve abundant useful biological active substances. Secang, a local name of Caesalpinia sappan (Leguminosae), promise high possibility for a broad-ranging purposes due to its biological activities. In traditional manner, the wood of secang is used for coloring agent for beverages, foods and cosmetics. Several phytochemicals were isolated from the secang extract, including brazilin, brazilein, protosappanin, 4-O-methyl sappanol, caesalpin, kampesterol and b-sitosterol. Secang extract and the compounds thereform have been reported to possess a huge variety of biological activities such as antioxidant, antibacterial, antifungal, anticancer, natural contraceptive and xanthine oxidase $(X O)$ inhibitor. The biologicai activities of the extracts and phytochemicals from secang may give scientific basis for their application in agricultural, food processing, medical and other industries.
\end{abstract}

Key words : Aktifitas biologis, Caesalpinia sappan, pemanfaatan ekstrak, secang

\section{PENDAHULUAN}

Kawasan hutan tropis Indonesia meliputi 110 juta hektar dan mengandung kurang lebih $80 \%$ tumbuhan obat yang terdapat di dunia.Diperkirakan di dalam hutan tropis Indonesia terdapat sekitar 28.000 jenis tumbuhan dan lebih dari 7.000 jenis di antaranya merupakan tumbuhan obat, atau setara dengan $90 \%$ jumlah tumbuhan obat yang dikenal di Asia. Sejauh ini, 1.000 jenis di antaranya telah dikenal dan dimanfaatkan secara luas sebagai obat tradisional (Pramono 2002). Dalam kaitan sebagai obat tradisional dan salah satu bentuk perawatan kesehatan yang efisien, aman, murah dan terjangkau oleh masyarakat, terlebih yang berdiam di daerah-daerah terpencil, tumbuhan obat memegang peran penting dalam kajian-kajian modern khususnya mengenai aktifitas biologis dari bahan alam. Dalam beberapa dekade terakhir, penerapan pengobatan tradisional telah meningkat tajam, yang kemungkinan disebabkan karena masyarakat semakin tidak dapat mengakses dan menjangkau pengobatan secara formal dan modern. Pada tulisan ini, dipaparkan secara ringkas potensi aktifitas biologis dan pemanfaatan salah satu tumbuhan potensiai di Kalimantan Timur, yang kiranya dapat memberikan dasar ilmiah bagi pemaniaatannya secara optimal.

\section{Tumbuhan Secang}

Secang (Caesalpinia sappan Linn.) merupakan salah satu jenis tumbuhan yang dapat dijumpai di beberapa lokasi di Kalimantan Timur, termasuk di Kabupaten Paser dan Kutai Barat. Tumbuhan yang secara lokal dikenal sebagai sopakng atau sepang ini merupakan tumbuhan multiguna dengan potensi pemanfaatan yang sangat tinggi. Asal usul daerah asli secang belum diketahui, namun diduga tumbuhan ini berasal dari daerah bagian tengah dan selatan India, kemudian ke Burma, Thailand, Indo-Cina dan Cina Selatan hingga ke Semenanjung Malaysia. 
Tumbuhan ini telah dibudidayakan dan telah dapat tumbuh secara alami di banyak tempat di Malesia (Indonesia, Filippina, PapuaNew Guinea) dan juga di India, Sri Lanka, Taiwan, Kepulauan Solomon, dan Hawaii. Tumbuhan Secang termasuk tumbuhan perdu, dengan ketinggian dapat mencapai lebih dari enam meter. Kayunya keras dan liat sehingga sangat sulit untuk dipotong. Banyak masyarakat yang mengenal tumbuhan ini, namun sangat sedikit yang tahu akan kegunaannya. Bahkan, di daerah-daerah tertentu, masyarakat sering menggunakan tumbuhan ini sebagai bahan kayu bakar dan sedikit digunakan untuk keperluan pengobatan tradisional. Rendaman atau seduhan air panas kayu secang ini berwarna merah dikenal sebagai obat manjur penyakit yang ditandai keluarnya darah seperti demam berdarah, mimisan, muntah darah, berak darah bahkan penyakit darah tinggi, juga untuk menyembuhkan penyakit gula darah (DM), jantung, infeksi ginjal dan lever. Biji tumbuhan ini berfungsi sebagai bahan sedatif, kayu dan batangnya dapat mengobati tuberkulosis, diare dan disentri. Sedangkan daun-daunnya dapat dimanfaatkan untuk mempercepat pematangan buah pepaya dan mangga. Tumbuhan ini memiliki daya adaptasi terhadap lingkungan yang tinggi sehingga dapat dimanfaatkan sebagai tanaman penghijauan.
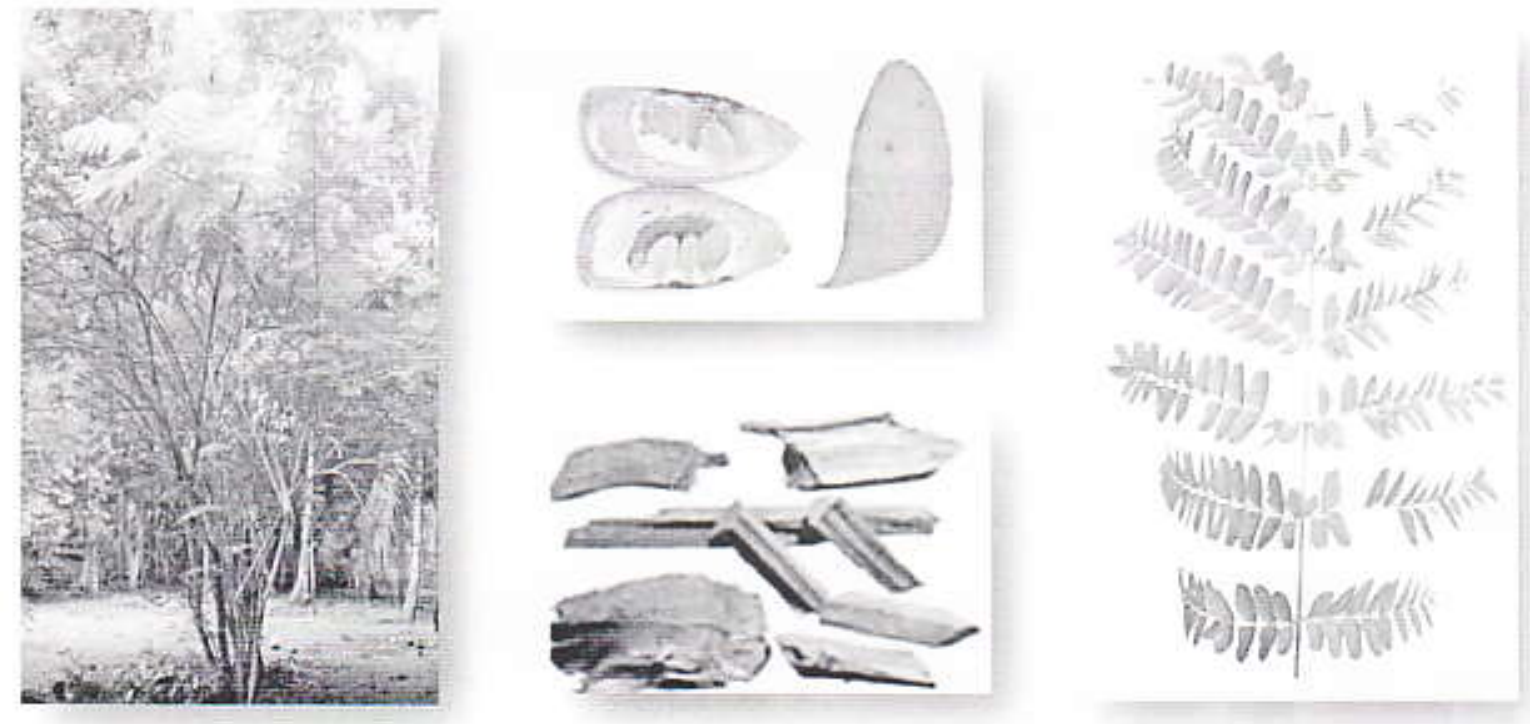

Gambar 1. Buah, kayu dan daun tumbuhan Secang (Caesalpinia sappan L.)

Hasil rebusan kayu Secang memiliki karakteristik warna merah dan tidak berbau, dengan kemampuan menghentikan perdarahan, pembersih darah, pengelat, penawar racun dan antiseptik. Daun dari tumbuhan secang mengandung minyak atsiri yang hampir tidak berwarna dan memiliki bau yang enak. Sedangkan kayunya bila direbus memberi warna merah gading muda, dapat digunakan untuk pengecatan, memberi warna pada bahan anyaman, kue, minuman atau sebagai tinta. Ekstrak kayu Secang selain bermanfaat sebagai obat muntah darah, berak darah, luka berdarah, memar berdarah juga berkhasiat mengobati diare, disentri, batuk darah (TBC), malaria, tetanus, dan tumor. Di Filipina, Indonesia dan India, kayu Secang dimanfaatkan sebagai sumber obat. Di Sulawesi Selatan serutan kayu secang dibuat minuman seperti teh yang dipercaya memiliki berbagai khasiat untuk kesehatan.

\section{Kajian Fitokimia Ekstrak Secang}

Tumbuhan secang kaya dengan berbagai kandungan kimia yang sudah diketahui, antara lain 
kayunya mengandung asam galat, tanin, resin, resorsin, brazilin, sappanin, brazilein, d-alphaphellandrene, oscimene, minyak atsiri, sedangkan daun mengandung $0,16 \%-0,20 \%$ minyak atsiri yang berbau enak dan hampir tidak berwarna. Senyawa-senyawa flavonoid (Namikoshi dan Saitoh 1987; Namikoshi et al. 1987; Namikoshi et al. 1987) dan fenolik (Fuke et al. 1985; Saitoh et al 1986) seperti 4-O-methylsappanol, protosappanin A (Nagai et al. 1986), protosappanin B (Nagai dan Nagumo 1986), protosappanin E, brazilin (Kim et al. 1997), brazilein, caesalpin J (Miyahara et al. 1986), triterpenoid dan steroid (seperti kampesterol, stigmasterol, â-sitosterol) telah diisolasi dari kayu secang.

Konstituen utama dari secang adalah brazilin, namun demikian brazilein juga terdapat dalam ekstrak, yang merupakan produk oksidasi dari brazilin dan dapat isolasi dalam jumlah besar bilamana ekstrak organik bereaksi dengan air dan udara. Brazilin sendiri memiliki aktifitas biologis yang demikian luas termasuk anti bakteri (Xu dan Lee 2004), sedangkan informasi mengenai aktifitas biologis dari brazilein masih sangat terbatas.<smiles>CO[C@H]1c2ccc(O)cc2OC[C@]1(O)Cc1ccc(O)c(O)c1</smiles><smiles>Oc1ccc2c(c1)OCC1(O)Cc3cc(O)c(O)cc3C21</smiles><smiles>O=C1COc2cc(O)ccc2-c2cc(O)c(O)cc2C1</smiles><smiles>O=C1C=CC2(c3cc(O)c(O)cc3C[C@H](O)CO)COCC2=C1</smiles>

4

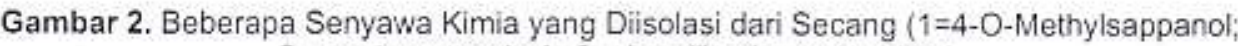
2 = protosappanin $\mathrm{A} ; 3$ = brazilin; $4=$ caesalpin $\mathrm{J}$.

Efek hepatoprotektif (Moon et al. 1992), imunomodulasi (Choi et al. 1997), hipoglikemia (Kim et al. 1995; Moon et al. 1988), antikomplementari (Oh et al. 1998), antikonvulsan (Baek et al. 2000), anti-peradangan, antibakteri (Niranjan Reddy et al. 2003), antioksidan (Badami et al. 2003; Yingming et al. 2004), dan aktifitas biologis lainnya dari secang telah pula dilaporkan.

\section{Aktifitas Biologis Ekstrak Secang}

\section{Ekstrak secang sebagai antioksidan alami}

Radikal bebas telah dikenal sebagai penyebab berbagai jenis penyakit, seperti penuaan dini, penyakit jantung koroner, peradangan, stroke, diabetes melitus, reumatik, kelainan fungsi hati dan kanker (Bulkley 1983; Dormandy 1983; Cheng et al. 2003). Jenis-jenis molekul dengan oksigen reaktif (reactive oxygen species, $\mathrm{ROS}$ ) yang meliputi $\mathrm{O} 2$ (anion superoksida), $\mathrm{OH}$ (radikal hidroksil), dan $\mathrm{H}_{2} \mathrm{O} 2$ (hidrogen peroksida) dapat menyebabkan gangguan pada sel dan juga menginisiasi peroksidasi asam lemak tak jenuh pada membran.

Mengingat peranannya yang multifungsi sebagai pencegah timbulnya berbagai jenis 
penyakit kronis, antioksidan akhir-akhir ini telah menarik perhatian para ahli dan peneliti di bidang kesehatan khususnya. Perhatian banyak ditujukan pada upaya pencarian zat-zat antioksidan yang potensial, berasal dari alam, terutama dari tumbuh-tumbuhan. Telah diketahui bahwa sebagian besar tumbuhan mengandung zat berkhasiat sebagai antioksidan, tetapi daya aktifitas setiap bahan umumnya berbeda-beda. Zat kimia alam yang terbukti memiliki potensi tinggi sebagai antioksidan adalah vitamin C, vitamin E, b-karotena, dan senyawa golongan polifenol seperti flavonoid, asam fenolat, tanin, dan lignin.

Tumbuhan secang (Caesalpinia sappan) yang biasa digunakan sebagai obat tradisional terbukti memiliki khasiat antioksidan yang kuat. Pengujian aktifitas antioksidan dari ekstrak kayu Secang baik secara in vitro maupun in vivo menunjukkan bahwa ekstrak air dan alkohol memiliki aktifitas yang setara bahkan lebih baik dibandingkan dengan antioksidan komersial yang tersedia saat ini, yaitu vitamin C dan rutin. Lebih lanjut, ekstrak etanol Secang memiliki daya peredaman radikal bebas superoksida hingga mencapai $100 \%$. Studi kimia tumbuhan ini mengungkapkan adanya lima senyawa aktif yang berperan sebagai antioksidan dan beberapa di antaranya tidak hanya mampu meredam radikal superoksida, tetapi juga memberikan efek peredaman yang sangat berarti, terhadap radikal hidroksil yang lebih reaktif dan berbahaya. Bahkan pada konsentrasi tertentu efeknya lebih kuat dari efek zat antioksidan alam yang sudah banyak dikenal, seperti vitamin $\mathrm{C}$, vitamin $\mathrm{E}$, dan betakaroten, dan antioksidan sintetik, butylated hydroxytoluen (BHT) (Safitriet al. 2003).

\section{Aktifitas anti-mikroba ekstrak Secang}

Ekstrak metanol Secang telah diuji aktifitasnya terhadap beberapa bakteri dan jamur patogen, termasuk Staphyloccus aureus dan Beauveria bassiana (Niranjan Reddy et al. 2003; Kim et al. 2004). Hasil penelitian di Laboratorium Kimia Kayu, Fakultas Kehutanan UNMUL, menunjukkan hasil bahwa ekstrak metanol Secang tidak hanya aktif menghambat pertumbuhan bakteri-bakteri patogen seperti E. coli dan Salmonella, namun juga terbukti mampu menghambat pertumbuhan jamur-jamur airborne secara signifikan. Ekstrak Secang juga terbukti aktif menghambat pertumbuhan beberapa jenis bakteri yang terkait dengan organ pencernaan (Lim 2007). Dengan karakteristik anti mikroba, pemanfaatan ekstrak Secang sebagai aditif pada makanan, aditif pada produk perawatan pribadi (personal care), penanganan berbagai infeksi mikroba dan aplikasi lain menjadi sangat dimungkinkan. Terkait dengan pemanfaatan ekstrak Secang sebagai anti mikroba, Balai Riset Industri, Samarinda dan Fakultas Kehutanan UNMUL saat ini sedang mengkaji peluang pembuatan cat berkualitas tinggi dengan aditif ekstrak Secang, khususnya untuk sifat ketahanan cat terhadap airborne dan indoor spore.

\section{Aktifitas anti-kanker ekstrak secang}

Kanker adalah salah satu penyebab utama kematian di negara-negara maju, di samping penyakit jantung dan pembuluh otak. Kanker secara klinis ditangani melalui operasi, radioterapi dan kemoterapi. Pada penanganan secara operasi, meskipun sebagian besar sel kanker dapat dihentikan pertumbuhannya, namun sel-sel yang telah mengalami metastasis tetap tumbuh. Hal ini menjadi salah satu penyebab yang membuat penanganan kanker menjadi sulit. Di sisi lain, meskipun penanganan melalui radioterapi dan kemoterapi mampu merusak DNA atau menghambat duplikasi DNA sehingga mampu membunuh sel tumor yang tumbuh secara cepat, namun pada saat yang sama metode ini juga mengakibatkan berbagai efek negatif termasuk 
kerontokan rambut (Ueda et al. 2002).

Penelitian yang dilakukan oleh Koshimizu et al. dari Kinki University Jepang tahun 1999 menunjukkan, ekstrak etanol tumbuhan Secang memiliki aktifitas anti pencetus tumor (anti tumor promoting activity) pada pengujian dengan metode penghambatan aktifitas Epstein-Barr virus yang diinduksi dengan tumor promoter 12-0-hexadecanoylphorbol-13-acetate. Ekstrak Secang juga menunjukkan aktifitas anti kanker pada sel kanker di leher dan kepala melalui peningkatan ekspresi p53 and p21WAF1/CIP1 (Kim et al. 2005).

Lebih lanjut, efek anti kanker dari ekstrak metanol kayu secang pada sel karsinoma oral (KB) dan osteosarkoma (HOS) telah dikaji dan dilaporkan oleh Lee et al. (2007). Mekanisme aktifitas anti kanker dianalisis melalui aktifitas penghambatan telomerase. Pada pengujian tersebut, ekstrak metanol kayu secang memperlihatkan adanya penghambatan terhadap telomerase yang sangat diperlukan bagi kehidupan sel kanker. Oleh karenanya, berdasarkan hasil penelitiannya, Lee et al (2007) menyimpulkan bahwa aktifitas anti kanker ekstrak kayu secang berkaitan dengan efek penghambatan pada telomerase.

\section{Ekstrak secang sebagai bahan kontrasepsi alami}

Pengertian umum kontrasepsi adalah berbagai cara untuk mencegah kehamilan. Obat kontrasepsi mempengaruhi pada 3 bagian proses reproduksi pria yang dapat dipengaruhi obat yaitu proses spermatogenesis, proses maturasi sperma dan transportasi sperma. Sedang kontrasepsi yang mempengaruhi proses reproduksi wanita antara lain, menghambat ovulasi, menghambat penetrasi sperma, menghambat fertilisasi dan menghambat implantasi.

Hasil penelitian Shih et al. (1990) pada 4 relawan selama 4 minggu menunjukkan bahwa Caesalpinia sappan memiliki potensi secara klinis untuk digunakan sebagai kontrasepsi oral pada pria, sebagaimana ditunjukkan pula oleh beberapa jenis obat herbal lain seperti Daemonorops draco, Melaphis chinensis, dan Phytolacca esculenta.

Berdasarkan hasil penelitian di Indonesia, ekstrak kayu Secang dapat dipakai sebagai bahan kontrasepsi pria dengan sasaran menghambat spermatogenesis dan sistem hormon, dengan tidak memperlihatkan efek racun berdasarkan hasil penelitian toksisitas akut pada hewan uji. Cara ber-KB tradisional ini bisa dikembangkan dengan memanfaatkan kayu secang (Caesalpinia sappan L) sebagai fitofarmaka (Winarno dan Sundari 1997; Nugroho 2003).

\section{Kemampuan ekstrak secang untuk menurunkan kadar asam urat}

Gout adalah salah satu penyakit yang umum dengan penyebaran yang demikian luas di dunia. Hyperuricemia, yang berhubungan dengan gout merupakan akibat dari produksi berlebih atau gangguan pada pembuangan asam urat (uric acid) dan sangatdipengaruhi oleh konsumsi yang berlebihan pada makanan-makanan yang kaya akan asam-asam nukleat seperti daging. kacang-kacangan, beberapa jenis seafoods, dan ragi makanan (Owen dan Jhons 199). Pada tahap akhir metabolisme purin, xanthine oxidase $(X O)$ mengkatalis proses oksidasi dari xantine dan hypoxanthine menjadi asam urat (Oettl dan Reibnegger 1999). Bahan dengan kemampuan penghambatan $\mathrm{XO}$ berpotensi untuk menghambat proses biosintesis asam urat dan umumnya digunakan dalam penanganan penyakit gout. Secara empiris tanaman Secang telah digunakan untuk mengatasi gout, rematik dan pembengkakan. Beberapa senyawa aktif dari ekstrak metanoi Secang telah terbukti berperan sebagai agen penghambat Xanthine oxidase (Thi et al. 2005). Senyawa aktif yang terkandung dalam tanaman secang diduga bertanggung jawab dalam 
menghambat produksi asam urat di tubuh, sehingga produksi komplikasi hiperurecimea berupa gout arthritis tidak terjadi. Penelitian untuk mengetahui aktifitas ekstrak etanol kayu Secang $70 \%$ sebagai penurun asam urat darah pada tikus telah dilakukan. Hasil penelitian menunjukkan dosis $40 \mathrm{mg} / \mathrm{kg}$ bb ekstrak etanol Secang menghasilkan penurunan kadar asam urat darah yang paling besar dibandingkan dengan dosis lain dan setara dengan alupurinol $50 \mathrm{mg} / \mathrm{kg}$ bb. Ekstrak kayu secang dosis $40 \mathrm{mg} / \mathrm{kg}$ bb dapat digunakan sebagai salah satu alternatif dalam penanganan kasus hiperuricemia, karena mempunyai aktifitas yang setara dengan aktifitas alopurinol dosis $50 \mathrm{mg} / \mathrm{kg}$ bb (Triyono et al. 2007).

\section{Toksisitas ekstrak secang}

Berbasis pada bervariasinya pemanfaatan ekstrak Secang, aspek keamanan penggunaannya perlu menjadi perhatian. Hingga saat ini penelitian untuk menguji keamanan penggunaan ekstrak Secang menunjukkan bahwa ekstrak kayu secang tidak memperlihatkan efek toksik berdasarkan uji toksisitas reproduksi dengan hewan coba tikus putih, uji mutagenik. Berdasarkan uji toksisitas sub kronik pada Macaca fascicularis L, jumlah sel darah merah menurun dan sel darah putih mengalami kenaikan. Hasil histologi pemberian ekstrak kayu secang dosis 875 mg/ek selama tiga bulan tidak memperlihatkan adanya kelainan untuk organ hati, ginjal dan limpa (Nugroho 2002). Lebih lanjut, hasil penelitian menunjukkan bahwa pada organ hati, ekstrak kayu secang menyebabkan megalositosis pada inti sel dan degenerasi sel (ekstrak etanol), focal degenerasi (fraksi kloroform), infiltrasi sel radang limfosit pada vena sentralis dan focal degenerasi sel hepar (fraksi air). Pada ginjal menyebabkan dilatasi sebagian tubuli (ekstrak etanol), squamous metaflasia (fraksi kloroform) dan ukuran epithel yang membesar (fraksi air), semua disertai dengan tetes-tetes protein dalam lumen tubulus. Secara umum kayu secang belum berefek buruk baik pada struktur histologis hepar maupun ren (Rusmiati dan Lestari 2004).

Di samping memperlihatkan berbagai bioaktifitas potensial sebagaimana disajikan pada paparan di atas, berbagai pengujian bioaktifitas ekstrak Secang telah dilakukan untuk aktifitas anti konvulsan, immunosuppresive, anti komplementari, aktifitas penurunan kadar gula darah, vasorelaksasi dan berbagai bioaktifitas lainnya (Xie et al. 2000; You et al. 2005; Ye et al, 2006).

\section{Potensi Pemanfaatan Secang \\ Bahan Pewarna Alami}

Zat warna alam untuk bahan tekstil pada umumnya diperoleh dari hasil ekstrak berbagai bagian tumbuhan seperti akar, kayu, daun, biji ataupun bunga. Pengrajin-pengrajin batik telah banyak mengenal tumbuhan-tumbuhan yang dapat mewarnai bahan tekstil beberapa diantaranya adalah : daun pohon nila (indofera), kulit pohon soga tingi (Ceriops candolleana arn), kayu tegeran (Cudraina javanensis), kunyit (Curcuma), akar mengkudu (Morinda citrifelia), kulit soga jambal (Pelthophorum ferruginum), kesumba (Bixa orelana), daun jambu biji (Psidium guajava). Bahan tekstil yang diwarnai dengan zat warna alam adalah bahan-bahan yang berasal dari serat alam contohnya sutera,wol dan kapas (katun). Bahan-bahan dari serat sintetis seperti polyester, nilon dan lainnya tidak memiliki afinitas atau daya tarik terhadap zat warna alam sehingga bahan-bahan ini sulit diwarnai dengan zat warna alam. Bahan dari sutera pada umumnya memiliki afinitas paling bagus terhadap zat warna alam dibandingkan dengan bahan dari kapas.

Bahan pewarna dari Secang dapat dimanfaatkan untuk pewarnaan makanan, kulit, sutera, batik, perkakas, lantai dan produk-produk kerajinan tangan. Di Indonesia, kayu Secang 
dimanfaatkan sebagai pewarna merah minuman. Di India, bahan pewarna alami dari Secang telah dimanfaatkan pada industri karpet, termasuk karpet sutera berkualitas tinggi yang merupakan salah satu kerajinan tangan India yang sangat terkenal di dunia. Zat pewarna alami dari Secang dapat diperoleh dengan merebus potongan atau serpih kayu Secang. Sappanin, brasilin, haematoxylin adalah senyawa-senyawa kimia yang memberikan karakteristik warna yang menarik pada ekstrak secang. Larutan campuran brazilin dan sappanin memberikan warna kemerahan pada ekstrak, sedangkan haematoxylin memberikan warna ungu.

Di India, produksi ekstrak kasar secang telah digunakan secara tradisional untuk pewarna alami, penyamakan kulit dan pengobatan tradisional. Di samping itu residu padatan dari secang digunakan pula sebagai bahan pewarna murah dan pengawet untuk kanvas dan jaring nelayan dan penyamakan kulit (Anonimous, 2008)

Di Indonesia, kebutuhan pasokan simplisia Secang mencapai 3-4 ton/tahun untuk memenuhi kebutuhan PT Sidomuncul, PT Air Mancur, PT Indo Farma, Dayang Sumbi, CV Temu Kencono, Indotraco, PT Nyonya Meneer, Herba Agronusa dan Jamu Jenggot (Anonimous 2007). Produk-produk olahan yang telah dikembangkan secara industri rumah tangga meliputi pengembangan produk Secang celup dan sirup secang. Dalam proses pembuatannya, Secang celup merupakan kombinasi dari bahan-bahan rempah-rempah diantaranya kayu Secang yang dibuat seperti serutan kayu, kapulogo dan jahe merah yang berfungsi sebagai penambah aroma dan rasa. Kemudian bahan-bahan ini dikeringkan, disebarkan dan dicampur menjadi satu dan setelah itu dimasukkan ke dalam kertas saring. Dalam unit kewirausaahan yang dikembangkan saat ini, secang dibuat dalam bentuk sachet (kantong). CV Jamasa di Yogyakarta telah memproduksi secang celup dengan komposisi: secang, jahe, sere, cengkeh, dan rempah-rempah; sedangkan sirup secang dibuat dengan memadukan secang dengan jahe, sere, rempah-rempah, cengkeh, dan gula.

Mengacu pada luasnya beragamnya aktifitas biologis yang dimiliki oleh ekstrak secang dan komponen aktifnya, tumbuhan ini memiliki potensi yang tinggi untuk menjadi bahan baku industri baik di bidang pertanian, pangan maupun medis.

\section{Tinjauan Paten}

Bersama-sama dengan beberapa jenis tumbuhan Indonesia lainnya, Secang telah dipatenkan di Jepang untuk penggunaannya sebagai agen penghambat produksi nitric oxide dengan nomor paten: JP2000034233, dengan aspek yang dipatenkan: Agen Penghambatan produksi nitric oxide (aktifitas antioksidan) dari Andrographis paniculata, Caesalpinia sappan, Schima wallichii, Alstonia scholaris, Graptophyllum pictum, Rheum officinale, Sindora javanica, Vitex trifolia, Anacardium occidentale, Gumnopetalum leucosticum, Equisetum debile, Kyllinga monocephala, Kyllinga vrevifolia, Ardisia fuliginosa, Entada phaseoloides (sumber: Hasil survei dari Database Paten Eropa, http://ep.espacenet.com).

Lebih lanjut, metode untuk produksi brazilein, salah satu senyawa aktif pada ekstrak secang, dengan cara kristalisasi senyawa telah dipatenkan oleh Korea Institute of Science and Technology dengan nomor publikasi: WO/2007/066926. Metode ini memungkinkan produksi brazilein dalam skala besar dengan cara yang cukup sederhana dan tidak memerlukan teknologi yang mahal termasuk penggunaan berbagai alat pemisahan senyawa seperti kromatografi kolom, supercritical fluid extractor maupun kromatografi cair kinerja tinggi (high-performance liquid chromatography, HPLC). Kondisi ini menjadikan metode produksi brazilein ini menjadi salah satu 
metode yang efisien dan dapat diaplikasikan secara industri.

Pemanfaatan ekstrak secang dan senyawa isolatnya sebagai agen penghambat angiogenesis telah pula dipatenkan oleh Korea Institute of Science and Technology dengan nomor publikasi: WO/2007/066928. Angiogenesis merupakan proses pembentukan pembuluh kapiler baru dari pembuluh kapiler yang lama. Proses ini umumnya berlangsung pada saat perkembangan janin, regenerasi jaringan tubuh dan penyembuhan luka yang berlangsung sangat teratur dalam tubuh. Ketidakteraturan proses ini, atau abnormal angiogenesis, akan berimplikasi pada munculnya berbagai penyakit yang berhubungan dengan pembuluh, gangguan pada mata, peradangan, gangguan pada kulit, alzheimer's, obesitas hingga kanker. Dengan sendirinya, bahan-bahan yang memiliki aktifitas untuk menghambat angiogenesis dapat digunakan dalam terapi penyakit-penyakit yang berhubungan dengan abnormalitas angiogenesis.

\section{KESIMPULAN}

Berbasis pada paparan di atas, terlihat jelas bahwa tumbuhan Secang merupakan salah satu tumbuhan dengan potensi pemanfaatan yang demikian luas. Secang yang dapat tumbuh dengan baik di Kalimantan Timur relatif belum banyak dikenal dan dikembangkan pemanfaatannya. Berdasarkan kemudahan budidaya tumbuhan ini, pemanfaatan tumbuhan Secang, baik sebagai simplisia atau pun ekstraknya untuk berbagai diversifikasi produk perlu mendapatkan perhatian dan dukungan serius. Disamping akan berpeluang menjadi salah satu produk andalan Kaltim, upaya ini akan bersinergi dengan upaya optimalisasi pemanfaatan sumberdaya alam untuk peningkatan kesejahteraan masyarakat di Kalimantan Timur. Di sisi lain, perlindungan hak kekayaan intelektual, dalam penerbitan paten dan hak cipta untuk pemanfaatan tertentu tumbuhan ini, menjadi sangat penting pula untuk diupayakan.

\section{DAFTAR PUSTAKA}

Anonimous. 2007. Pasar Domestik dan Ekspor Produk Tanaman Obat. Pusat Studi Biofarmaka, Bogor. Tersedia di: http://seafast.ipb.ac.id/seafast.info/informasi gratis/PASAR DOMESTIK DAN EKSPORPRODUK TANAMAN OBAT.pdf. Di akses: 27 Desember 2007.

Anonimous. 2008. Natural Colours. Tersedia di: http://www.sssbiotic.com/product/naturalcolors1.asp. Diakses 15 Pebruari 2008.

Badami S, Moorkoth S, Rai S.R, Kannan E, Bhojraj S. 2003. Antioxidant activity of Caesalpinia sappan heartwood. Biol. Pharm. Bull. 26:1534-1537.

Baek NI, Jeon SG, Ahn EM, Hahn JT, Bahn JH, Cho SW. 2000. Anticonvulsant compounds from the wood of Caesalpinia sappan L. Arch. Pharmacal. Res. 23: 344-348.

Bulkley GB. 1983. The role of oxygen free radicals in human disease. Surgery 94: 407-411.

Cheng HY, Lin TC, Yu KH, Yang CM, Lin CC. 2003. Antioxidant and free radical scavenging activities of Terminalia chebula. Biol. Pharm. Bull. 26:1331-1335.

Choi SY, Yang KM, Jeon SD, Kim JH, Khil LY, Chang TS. 1997. Brazilin modulates immune function mainly by augmenting $T$ cell activity in halothane administered mice. Planta Medica 63:405408.

Dormandy TL. 1983. An approach to free radicals. Lancet 11:1010-1014.

Fuke C, Yamahara J, Shimokawa T, Kinjo J. Tomimatsu T, Nohara T. 1985. Two aromatic compounds related to brazilin from Caesalpinia sappan. Phytochemistry 24: 2403-2406.

Kim EC, Hwang YS, Lee HJ, Lee SK, Park MH, Jeon BH, Jeon CD, You YO. 2005. Caesalpinia 
sappan induces cell death by increasing the expression of $p 53$ and $p 21$ WAF1/CIP1 in head and neck cancer cells. The American journal of Chinese medicine 33:405-414.

Kim KJ, Yu HH, Jeong SI, Cha JD, Kim SM, You YO. 2004. Inhibitory effects of Caesalpinia sappan on growth and invasion of methicillin-resistant Staphylococcus aureus. J. Ethnopharmacol. 91:81-87.

Kim DS, Baek NI, Oh SR, Jung KY, Lee IS, Lee HK. 1997. NMR assignment of brazilin. Phytochemistry 46:177-178.

Kim, YM, Kim SG, Khil LY, Moon CK. 1995. Brazilin stimulates the glucose transport in 3T3-L1 cells. Planta Medica 61:297-301.

Lee JS, Kim JH, Kim YG. 2001. Studies on anticancer effects of extracts caesalpinia sappan on oral carcinoma and osteosarcoma cells. Korean Assoc Oral Maxillofac Surg. 27:281-288.

Lim MY, Jeon JH, Jeong EY, Lee CH, Lee HS. 2007. Antimicrobial activity of 5-hydroxy-1,4naphthoquinone isolated from Caesalpinia sappan toward intestinal bacteria. Food Chemistry 100:1254-1258.

Miyahara K, Kawasaki T, Kinojo J E, Shimokawa T, Yamahara J, Yamasaki M. 1986. The X-ray analysis of caesalpin J from sappan lignum. Chem. Pharm. Bull. 34:4166-4169.

Moon CK, Chung JH, Lee YM, Lee SH, Hwang GS, Park KS. 1988. Effects of brazilin on erythrocyte deformability and its related biochemical factors in streptozotocin induced diabetic rats. Arch. Pharm. Res. 11:149-154.

Moon CK, Park KS, Kim SG, Won HS, Chung JH. 1992. Brazilin protects cultured rat hepatocytes from trichlorobromethane-induced toxicity. Drug and Chemical Toxicology 15:81-91.

Nagai M, Nagumo S. 1986. Protosappanin B, a new dibenzoxocin derivative from sappan lignum (Caesalpinia sappan). Heterocycles 24:601-606.

Nagai M, Nagumo S, Lee SM, Eguchi I, Kawai KI. 1986. Protosappanin A, a novel biphenyl compound from sappan lignum. Chem. Pharm. Bul.34:1-6.

Namikoshi M, Saitoh T. 1987. Homoisoflavonoids and related compounds: IV. Absolute configurations of homoisoflavonoids from Caesalpinia sappan L. Chem. Pharm. Bull. 35:3597-3602.

Namikoshi M, Nakata H, Saitoh T. 1987. Homoisoflavonoids and related compounds: V. A novel dibenzoxocin derivative from Caesalpinia sappan L. Chem. Pharm. Bull. 35:3615-3619.

Namikoshi M, Nakata H, Yamda H, Nagai M, Saitoh T. 1987. Homoisoflavonoids and related compounds: II. Isolation and absolute configurations of 3,4-dihydroxylated homoisoflavans and brazilins from Caesalpinia sappan L. Chem. Pharm. Bull. 35: 2761-2773.

Niranjan-Reddy VL, Ravikanth V, Jansi-Lakshmi VVNS, Suryanarayan-Murty U, Venkateswarlu Y. 2003. Inhibitory activity of homoisoflavonoids from Caesalpinia sappan against Beauveria bassiana. Fitoterapia 74:600-602.

Nugroho YA. 2002. Pengembangan Kayu Secang (Caesalpinia sappan L) sebagai Fitofarmaka. Laporan Penelitian JKPKBPPK. Litbang Depkes. Jakarta.

Nugroho YA. 2003. Pengembangan Kayu Secang (Caesalpinia sappan L) sebagai Fitofarmaka Antifertilitas : Uji Toksisitas Sub Kronik pada Hewan Non rodent, Uji Toksisitas Reproduksi, Mutagenik dan Pengembangan Sediaan. Laporan Penelitian JKPKBPPK. Litbang Depkes. Jakarta.

Oettl K, Reibnegger G. 1999. Pteridines as inhibitors of xanthine oxidase: structural requirements. Biochim. Biophys. Acta 1430:387-395. 
Oh SR, Kim DS, Lee IS, Jung KY, Lee JJ, Lee HK. 1998. Anticomplementary activity of constituents from the heartwood of Caesalpinia sappan. Planta Medica 64:456-458.

Owen PL, Jhons T. 1999 Xanthine oxidase inhibitory activity of northeastern North American plant remedies used for gout. J. Ethnopharmacol. 64:149-160.

Pramono E. 2002. The commercial use of traditional knowledge and medicinal plants in Indonesia. Article Submitted for Multi-Stakeholder Dialoque on Trade, Intellectual Property and Biological Resources in Asia, BRAC Centre for Development Management, Rajendrapur, Bangladesh, April 19-21,2002.13pp.

Rusmiati, Lestari A. 2004. Struktur histologis organ hepar dan ren mencit (Mus musculus L) jantan setelah perlakuan dengan ekstrak kayu Secang (Caesalpinia sappan L). Bioscientiae 1:2330.

Safitri R, Tarigan P, Freisleben HJ, Rumampuk RJ, MurakamiA. 2003. Antioxidant activity in vitro of two aromatic compounds from Caesalpinia sappan L. BioFactors 19:71-77.

Saitoh T, Sakashita S, Nakata H. Shimokawa T, Kinjo K, Yamahara J. 1986. 3-Benzylchroman derivatives related to brazilin from sappan lignum. Chem. Pharm. Bull. 34:2506-2511.

Shih IM, Chiang HS, Yang LL, Wang TL. 1990. Antimotility effects of Chinese herbal medicines on human sperm. Journal of the Formosan Medical Association 89:466-469.

Thi NMT, Suresh A, Tezuka Y, Tran QL, Kadota S. 2005. Xanthine oxidase inhibitors from the heartwood of Vietnamese Caesalpinia sappan. Chem. Pharm. Bull. 53:984-988.

Triyono A, Prihartini A, Mujahid R. 2007. Uji Aktivitas Penurun Asam Urat Darah Ekstrak Etanol 70 \% Kayu Secang (Caesalpinia sappan L) pada Tikus. Balai Besar Litbang Tanaman Obat dan Obat Tradisional, Tawangmangu, Badan Litbang Kesehatan. Jakarta.

Ueda J. Tezuka Y, Banskota AH, Tran QL, Tran QK, Harimaya Y, Saiki I, Kadota S. 2002. Antiproliferative Activity of Vietnamese Medicinal Plants. Biol. Pharm. Bull. 25:753-760.

Winarno MW, Sundari D. 1997. Informasi Tanaman Obat untuk Kontrasepsi Tradisional. Cermin Dunia Kedokteran 120:25-28.

Xie YW, Ming DS, Xu HX, Dong H, But PPH. 2000. Vasorelaxing effects of Caesalpinia sappanInvolvement of endogenous nitric oxide. Life Sciences Including Pharmacology Letters 67:1913-1918.

Xu HX, Lee SF. 2004. The antibacterial principle of Caesalpinia sappan. Phytother. Res. 18:64751.

Ye Min, Xie WD, Lei F, Meng Z, Zhao YN, Su H, Du LJ. 2006 Brazilein, an importantimmunosuppressive component from Caesalpinia sappan L. International immunopharmacology 6:426-432.

Yingming P, Ying L, Hengshan W, Min L. 2004. Antioxidant activities of several Chinese medicine herbs. Food Chemistry 88:347-350.

You EJ, Khil LY, Kwak WJ, Won HS, Chae SH, Lee BH, Moon CK. 2005. Effects of brazilin on the production of fructose-2,6-bisphosphate in rat hepatocytes. Journal of ethnopharmacology 102:53-57. 